\title{
Morphological and molecular characterization of two isolates of Paratrichodorus porosus from Shenzhen, China
}

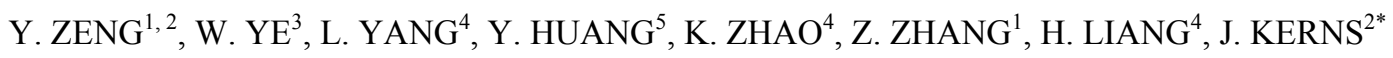 \\ ${ }^{1}$ Department of Plant Protection, Zhongkai University of Agriculture and Engineering, Guangzhou, 510225, People's \\ Republic of China, E-mail: zys65@163.com; ${ }^{2}$ Department of Plant Pathology, North Carolina State University, \\ Raleigh, NC 27695-7613, USA, "E-mail: jpkerns@ncsu.edu; ${ }^{3}$ Nematode Assay Section, Agronomic Division, \\ North Carolina Department of Agriculture and Consumer Services, Raleigh, NC 27607, USA; ${ }^{4}$ Shenzhen \\ Environmental Monitoring Center, Shenzhen, 518049, People's Republic of China; ${ }^{5}$ College of Life Science, \\ Zhongkai University of Agriculture and Engineering, Guangzhou, 510225, People's Republic of China
}

\begin{abstract}
Summary
Studies were conducted to characterize morphological and molecular profiles of two isolates of Paratrichodorus porosus (SZ1 and SZ2) which were recovered from Acacia mangium in Tianxinshan and Gleichenia linearis in Yangmeikeng environmental monitoring sites in Shenzhen, China, respectively. Analysis of morphometric, morphological and molecular characters revealed these two Shenzhen isolates are identical to P. porosus. Measurements of both study isolates lie within the ranges for $P$. porosus. It is typologically characterized by possessing a clearly swollen body cuticle after fixation, an onchiostyle ventrally curved, 46 - $58 \mu \mathrm{m}$ long, a pharyngeal bulb usually with a well developed anterior-dorsal intestinal overlap, a secretoryexcretory pore opening between the nerve ring and anterior end of pharyngeal bulb, $90-110 \mu \mathrm{m}$ from the anterior end, a reproductive system with didelphic, amphidelphic, without spermathecae, a pore-like vulva in ventral view and occupying $52.0 \%-59.5 \%$ of total body length from anterior end, a short and barrel-shaped vagina with small sclerotizations, a pair of ventromedian advulvar body pores located prevulvar and postvulvar, a rounded tail and a subterminal anus in females. The sequence analysis based on partial rDNA $18 \mathrm{~S}$ gene and 28S D2/D3 expansion segment confirm its identity as $P$. porosus. This is the first report of $P$. porosus associated with A. mangium and $G$. linearis.
\end{abstract}

Keywords: Paratrichodorus porosus; Acacia mangium; Gleichenia linearis; 18S small subunit rDNA; 28S large subunit rDNA; PCR; stubby-root nematode; taxonomy

\section{Introduction}

Paratrichodorus Siddiqi, 1974 is a cosmopolitan stubbyroot nematode genus occurring mainly in tropical and subtropical regions (Hunt, 1993). Paratrichodorus species are migratory ectoparasites of roots. Nanidorus minor (Colbran, 1956) Siddiqi, 1974, which was formerly known as Trichodorus christiei, was first ectoparasitic nematodes shown to damage plants (Christie \& Perry, 1951). Significant crop losses due to Paratrichodorous and other trichodorids, both as plant parasites and as vectors of plant-pathogenic viruses, is a worldwide problem (Decraemer, 1991). Thirty-three nominal species in Paratrichodorus have been described. Among those, P. porosus (Allen, 1957) Siddiqi, 1974 is a widespread and economically important species that causes damage to sugarcane, camellia, maize, sorghum and grapes etc. It is distributed in 24 countries around the globe (CABI, 2009). In China it was found in Fujian, Yunnan, Zhejiang, Guangdong provinces (Zheng et al., 2004; Zhao et al., 2005; Liao et al., 2011).

$P$. porosus is designated as a quarantine pest by many countries (Seed Association of Thailand). It is known to transmit tobacco rattle virus (TRV) (Ayala \& Allen, 1968; Taylor \& Brown, 1997) and causes black-rot disease of Chinese yam (Dioscorea batatus) (Nishizawa, 1973). It also has a broad host range of up to 100 plant species (Decraemer, 1995; Sheedy et al., 2010) and is an important pest of many crops (Plantwise). Feeding by P. porosus on cells of root tips causes growth and elongation of roots to cease, and results in stubby-root symptoms. $P$. porosus causes extensive damage to the root system of Camellia (Barriga, 1965) and affects forage production in North Carolina, USA, by damaging maize and sorghum crops along with Tylenchorhynchus claytoni and Pratylenchus zeae (Chévres-Román et al., 1971). Heavy parasitism of them affected the uptake of nutrients and water in plants from the soil (Chévres-Román et al., 1971).

Accurate identification of trichodorids to the species level is crucial to implement appropriate control measures for these nematodes. Typically, trichodorid identification is based on analysis of morphological and morphometrical 
characters. However, differentiation of some species, mainly in Paratrichodorus is often difficult due to high intraspecific variability. Recently, DNA-based approaches have been successfully employed for the molecular diagnosis of trichodorids (Boutsika et al., 2004; Riga et al., 2007; Duarte et al., 2011; Kumari \& Subbotin, 2012). Kumari \& Subbotin (2012) reported that analysis of the D2/D3 of the 28S rDNA sequence data set revealed four unidentified species of Trichodorus, and the partial 18S rDNA sequence data set distinguished four unidentified species of Trichodorus and two unidentified species of Paratrichodorus. Duarte et al. (2011) developed a PCRRFLP assay based on the 18S rRNA gene for rapid identification of 12 trichodorid nematodes belonging to Trichodorus, Paratrichodorus and Nanidorus.

During a survey of nematodes in five environmental monitoring sites in Shenzhen, China in 2013, two Paratrichodorus isolates, SZ1 and SZ2, were recovered from soils around the roots of Acacia mangium Willd. in Tianxinshan and Gleichenia linearis (Burm. f.) Clarke in Yangmeikeng, respectively. Through this study, both nematode isolates were identified as P. porosus (Allen, 1957) Siddiqi, 1974, representing the first report of this nematode from $A$. mangium and $G$. linearis.

The main objectives of this study were to: (i) confirm the identity of two $P$. porosus isolates based on morphological and molecular approaches; and (ii) investigate their phylogenetic relationships with other Paratrichodorus species based upon sequence analysis of the $18 \mathrm{~S}$ and $28 \mathrm{~S}$ D2/D3 rDNA.

\section{Materials and methods}

\section{Morphological Characterization}

Nematode isolates SZ1 and SZ2 in this study were recovered from rhizospheric soils in A. mangium and G. linearis, respectively. Nematodes were extracted by a sieving and decanting method (Brown \& Boag, 1988). Specimens were heat-killed, fixed in $3 \%$ formaldehyde and processed to glycerin by the formalin-glycerin method (Hooper, 1970; Golden, 1990). Specimen preparation and measurements were as described in Golden and Birchfield (1972). Measurements of nematodes were performed with the aid of a camera lucida and a stage micrometer. The morphometric data were processed using Excel software (Ye, 1996). Photomicrographs were taken with a Leica video camera (DFC490) attached via a C-mount Adapter fitted on a
Leica microscope (DM4000B), and edited using Adobe Photoshop CS5. Morphological identification of specimens was done using keys provided by Decraemer (1995) and Decraemer and Baujard (1998), with corresponding species descriptions.

\section{Molecular Characterization}

For each isolate, three females were hand-picked into distilled water for DNA extraction, amplification, and sequencing. They were placed into $50 \mu \mathrm{l}$ of worm lysis buffer (WLB) containing Proteinase $\mathrm{K}$ for DNA extraction (Williams et al., 1992). DNA samples were stored at $20{ }^{\circ} \mathrm{C}$ until used as a PCR template.

The primers used for polymerase chain reaction (PCR) and DNA sequencing are presented in Table 1. Primers SSUF 07/SSUR26, 18S965/18S1573R and 18SnF/18SnR were used for PCR amplification and DNA sequencing for small subunit $18 \mathrm{~S}$ and D2A/D3B for large subunit 28S rDNA.

The $25 \mu$ PCR was performed using TaqMix DNA polymerase (Guangzhou Dongsheng Biotech Ltd., Guangzhou, China) according to the manufacturer's protocol. The thermal cycler program for PCR was as follows: denaturation at $95^{\circ} \mathrm{C}$ for 5 min followed by 35 cycles of denaturation at $94{ }^{\circ} \mathrm{C}$ with $30 \mathrm{~s}$; annealing at $55^{\circ} \mathrm{C}$ for $45 \mathrm{~s}$, and extension at $72^{\circ} \mathrm{C}$ for $2 \mathrm{~min}$. A final extension was performed at $72{ }^{\circ} \mathrm{C}$ for $10 \mathrm{~min}$ (Ye et al., 2007).

PCR products were cleaned using an EZ Spin Column DNA Gel Extraction Kit (Bio Basic Inc., Markham, Ontario, Canada) according to the manufacturer's protocol before being sequenced by Shanghai Sangon Biological Engineering Technology and Service Co., Ltd. (Shanghai, China) using an ABI PRISM 3730 sequencing system.

The nematode sequences from this project were deposited in genBank. We used DNA sequences with the highest matches with our isolates from the genBank database for phylogenetic analysis. DNA sequences were aligned using ClustalW (San Diego Supercomputer Center). The model of base substitution in the $18 \mathrm{~S}$ and $28 \mathrm{~S}$ sets was evaluated using MODELTEST version 3.06 (Posada \& Crandall, 1998). The Akaike-supported model, the proportion of invariable sites, and the gamma distribution shape parameters and substitution rates were used in phylogenetic analyses. Bayesian analysis was performed to confirm the tree topology for each gene separately using MrBayes 3.1.0 (Huelsenbeck \& Ronquist, 2001) running the chain for $10^{6}$ generations and setting the 'burn in' at 1000 . We used MCMC (Markov Chain Monte Carlo) methods within

Table 1. Primers used for polymerase chain reaction and DNA sequencing

\begin{tabular}{llll}
\hline Primer & Marker & Sequence (5' to 3') & Reference \\
\hline SSUF07 & $18 \mathrm{~S}$ & AAAGATTAAGCCATGCATG & Floyd et al. $(2002)$ \\
SSUR26 & $18 \mathrm{~S}$ & CATTCTTGGCAAATGCTTTCG & Floyd et al. $(2002)$ \\
18S965 & $18 \mathrm{~S}$ & GGCGATCAGATACCGCCCTAGTT & Mullin et al. $(2005)$ \\
18S1573R & $18 \mathrm{~S}$ & TACAAAGGGCAGGGACGTAAT & Mullin et al. (2005) \\
18SnF & $18 \mathrm{~S}$ & TGGATAACTGTGGTAATTCTAGAGC & Kanzaki and Futai (2002) \\
18SnR & $18 \mathrm{~S}$ & TTACGACTTTTGCCC GGTTC & Kanzaki and Futai (2002) \\
D2A & $28 \mathrm{~S}$ & ACAAGTACCGTGAGGGAAAGTTG & Nunn (1992) \\
D3B & $28 \mathrm{~S}$ & TGCGAAGGAACCAGCTACTA & Nunn (1992) \\
\hline
\end{tabular}




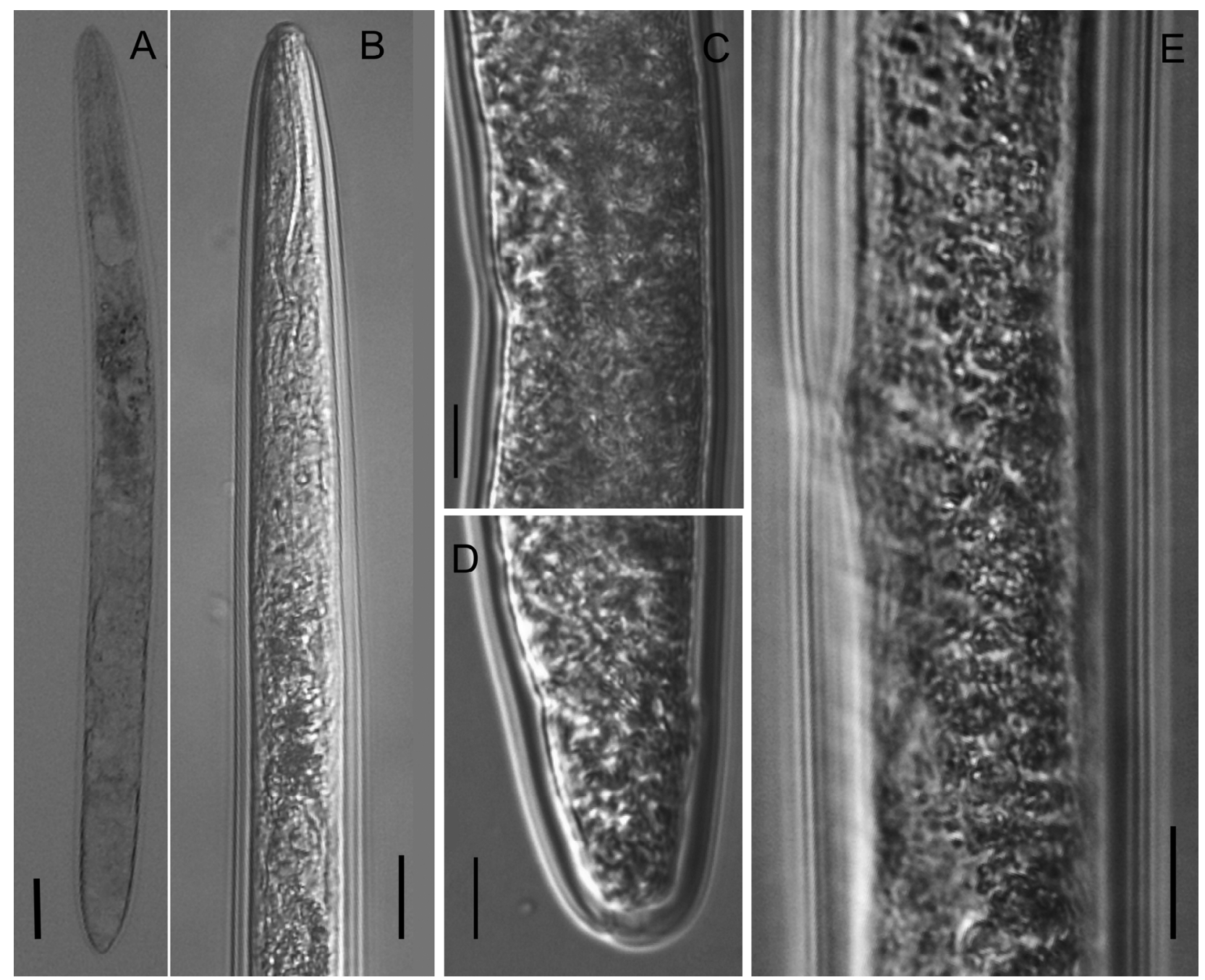

Fig. 1. Light micrographs of Paratrichodorus porosus from Acacia mangium and Gleichenia linearis. A: Female entire body; B: Female anterior body; C: Female onchiostyle; D: Female tail; E: Reproductive system of female. Scale bars: A=50 $\mu \mathrm{m} ; \mathrm{B}=20 \mu \mathrm{m} ; \mathrm{C}-\mathrm{E}=10 \mu \mathrm{m}$

a Bayesian framework to estimate the posterior probabilities of the phylogenetic trees (Larget \& Simon, 1999) using the $50 \%$ majority-rule.

\section{Results}

\section{Morphological description}

Morphometrics of females of two isolates of $P$. porosus are presented in Table 2. Measurements of both study isolates lie within the ranges previously reported for $P$. porosus (Decraemer, 1995; Zheng et al., 2004; Zhao et al., 2005; Liao et al., 2011). These two isolates are identical based on morphology and molecular characteristics, thus they are treated as the same species (but different geographical isolates) in the following description.

Female: General appearance typical for the genus. Body configuration usually rounded at both ends and straight when heat-killed (Fig. 1). Body cuticle clearly swollen after fixation, $3.5-5.0 \mu \mathrm{m}$ thick at mid-body. The onchiostyle ventrally curved, guide ring around or less than distal third of onchiostyle, at $15-20 \mu \mathrm{m}$ from anterior end. Pharyngeal bulb usually with a well developed anterior-dorsal intestinal overlap, bulb rarely offset. Secretory-excretory pore between nerve ring and anterior end of pharyngeal bulb. Reproductive system didelphic, amphidelphic, without spermathecae. Vulva pore-like in ventral view. Vagina short, barrel-shaped. Vaginal sclerotizations small, inconspicuous. One pair of ventromedian advulvar body pores, located prevulvar and postvulvar (one anterior and one posterior to vulva), lateral body pores absent. Rarely sperm in uteri. Tail rounded. Anus subterminal.

Male: Not found.

Morphometric and morphological analysis:

Morphometrics of $P$. porosus SZ1 did not differ from those of $P$. porosus SZ2, fitting in the ranges of those reported in the previous description except for a lower $b$ value from both SZ1 and SZ2 than that reported by Liao et al. (2011) $(4.3-4.8 v s 4.8-5.5)$, and a lower a value from $P$. porosus SZ1 than those reported by Liao et al. (2011) (14.3 16.5 vs 17.4 - 17.8) and Zheng et al. (2004) (14.3 - 16.5 vs 16.0 - 23.0) (Table 2). Morphologically, no apparent difference was found except for a smaller number of ventromedian advulvar body pores from study isolates than those reported by Zheng et al. (2004) and Zhao et al. (2005) (one 
Table 2. Morphometrics of females of studied isolates of Paratrichodorus porosus mounted in formalin-glycerin All measurements in $\mu \mathrm{m}$ and in the format: mean \pm s.d. (Range)

\begin{tabular}{|c|c|c|}
\hline Character & P. porosus $\mathrm{SZ} 1$ & P. porosus $\mathrm{SZ2}$ \\
\hline Host & Acacia mangium & Gleichenia linearis \\
\hline $\mathrm{n}$ & 10 & 10 \\
\hline $\mathrm{L}$ & $\begin{array}{c}568.5 \pm 42.3 \\
(520.8-601.5)\end{array}$ & $\begin{array}{c}589.8 \pm 75.2 \\
(532.6-700.2)\end{array}$ \\
\hline $\mathrm{a}$ & $\begin{array}{c}15.7 \pm 1.2 \\
(14.3-16.5)\end{array}$ & $\begin{array}{c}16.6 \pm 2.3 \\
(16.0-25.0)\end{array}$ \\
\hline $\mathrm{b}$ & $\begin{array}{c}4.5 \pm 0.2 \\
(4.3-4.7)\end{array}$ & $\begin{array}{c}4.5 \pm 0.2 \\
(4.4-4.8)\end{array}$ \\
\hline $\mathrm{V}$ & $\begin{array}{c}53.2 \pm 1.5 \\
(52.0-54.9)\end{array}$ & $\begin{array}{c}54.8 \pm 3.2 \\
(52.6-59.5)\end{array}$ \\
\hline Onchiostyle & $\begin{array}{c}51.1 \pm 6.5 \\
(45.8-58.3)\end{array}$ & $\begin{array}{c}51.0 \pm 4.8 \\
(45.8-57.4)\end{array}$ \\
\hline $\begin{array}{l}\text { Secretory-Excretory pore } \\
\text { from anterior end }\end{array}$ & $\begin{array}{c}98.3 \pm 5.0 \\
(93.0-103.0)\end{array}$ & $\begin{array}{c}97.8 \pm 9.0 \\
(90.0-110.0)\end{array}$ \\
\hline Vagina length & $\begin{array}{c}9.1 \pm 0.2 \\
(9.0-9.3)\end{array}$ & $\begin{array}{c}9.8 \pm 0.5 \\
(9.3-10.5)\end{array}$ \\
\hline Size of vaginal pieces & $\begin{array}{c}1.3 \pm 0.1 \\
(1.1-1.4)\end{array}$ & $\begin{array}{c}1.2 \pm 0.1 \\
(1.1-1.3)\end{array}$ \\
\hline Anterior genital branch & $\begin{array}{c}152.9 \pm 6.6 \\
(140.2-166.7)\end{array}$ & $\begin{array}{c}171.9 \pm 20.0 \\
(152.6-200.0)\end{array}$ \\
\hline Posterior genital branch & $\begin{array}{c}145.3 \pm 7.5 \\
(136.7-150.0)\end{array}$ & $\begin{array}{c}166.4 \pm 13.7 \\
(150.8-183.3)\end{array}$ \\
\hline Body diam. (greatest body diam.) & $\begin{array}{c}36.1 \pm 0.7 \\
(35.4-36.7)\end{array}$ & $\begin{array}{c}36.3 \pm 8.4 \\
(28.0-48.0)\end{array}$ \\
\hline Pharynx & $\begin{array}{c}126.0 \pm 6.6 \\
(120.0-133.0)\end{array}$ & $\begin{array}{c}130.1 \pm 11.0 \\
(121.8-146.2)\end{array}$ \\
\hline
\end{tabular}

pair $v s$ two pairs), than that reported by Liao et al. (2011) (one pair $v s$ three pairs), indicating intraspecies variability in the morphological characters among $P$. porosus isolates from different locations.

\section{Molecular Phylogenetic Relationships}

A 1131-bp 18S rDNA and a 732-bp 28S D2/D3 expansion segment were amplified and sequenced. Sequences of the rDNA were compared using blastN search from a diverse collection of Paratrichodorus species presented in genBank. Two $P$. porosus isolates (genBank accession No. KJ641548 and KJ641550 for SZ1 and KJ641549 and KJ641551 for SZ2) in this study are identical either for $18 \mathrm{~S}$ or $28 \mathrm{~S}$.

The alignment for the partial 18S rDNA included 71 sequences. Forty-six Paratrichodorus, nine Trichodorus and 16 Nanidorus nominal and putative isolates were included in this analysis. Two studied isolates of P. porosus is for 326
$99 \%$ identical with all other 19 Chinese isolates, one Portugal (DQ345524) and one American isolate (JN123368) of $P$. porosus, but $95 \%$ and $91 \%$ with one Brazil (AJ438059) and another Portugal isolate (AJ438060), respectively. Intraspecific sequence variations for $P$. porosus was $0 \%-6.1 \%(0-68 \mathrm{nt})$. Without Brazil (AJ438059) and Portugal isolate (AJ438060), the intraspecific sequence variations was $0 \%-0.3 \%(0-3 \mathrm{nt})$. The identities of both $P$. porosus isolates are $97 \%-98 \%$, $98 \%, 97 \%, 96 \%, 95 \%-97 \%, 90 \%-93 \%$ with $P$. teres, $P$. allius, $P$. pachydermus, $P$. divergens, $P$. hispanus, $P$. anemones, $93 \%, 93 \%, 93 \%$ with $N$. minor, $N$. renifer, N. nanus, and $93 \%-95 \%$ with Trichodorus spp. (T. beirensis, T. cylindricus, T. pakistanensis, T. primitivus, T. similis, T. sparsus and T. variopapillatus), respectively. Based on these data, the Brazil isolate (AJ438059, 95\% identity) and the Portugal isolate (AJ438060, $91 \%$ identity) are very likely different species rather than $P$. po- 


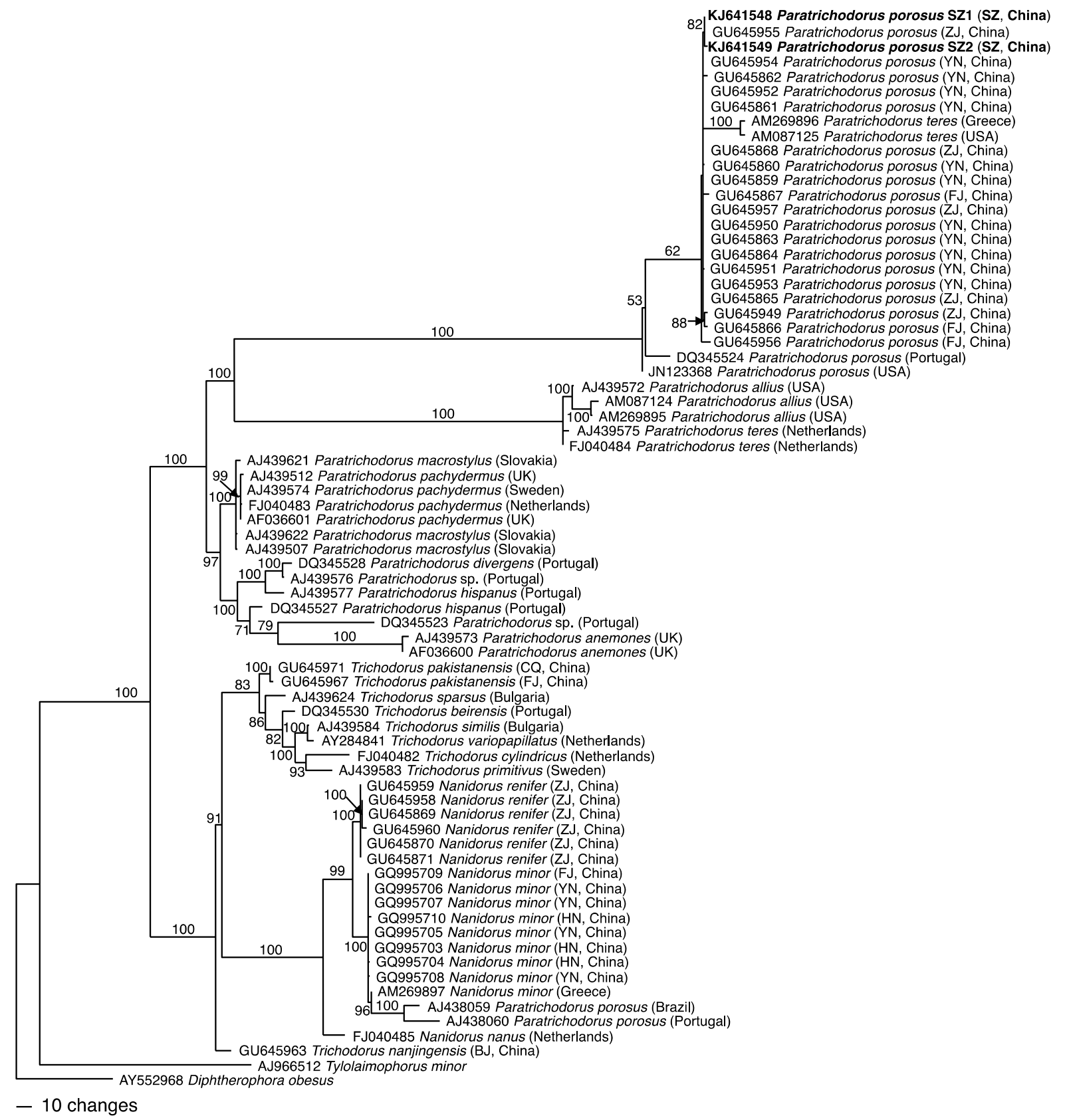

Fig. 2. The 10001 st Bayesian tree inferred from Paratrichodorus porosus $18 \mathrm{~S}$ under $\mathrm{GTR}+\mathrm{I}+\mathrm{G}$ model $(-\operatorname{lnL}=4871.895 ;$ freqA $=0.2775$; freqC $=0.2107$; freqG $=0.2603$; freqT $=0.2515 ; \mathrm{R}(\mathrm{a})=1.9822 ; \mathrm{R}(\mathrm{b})=3.5626 ; \mathrm{R}(\mathrm{c})=2.2002 ; \mathrm{R}(\mathrm{d})=0.8367 ; \mathrm{R}(\mathrm{e})=7.7939 ; \mathrm{R}(\mathrm{f})=1 ; \mathrm{Pinva}=0.4142$; Shape $=0.6124)$. Posterior probability values exceeding $50 \%$ are given on appropriate clades.

rosus. It's worthy to note that two isolates of $P$. teres (AM269896 and AM087125) are in a monophyletic clade with many other $P$. porosus isolates and are significantly different from two $P$. teres isolates (AJ439575 and FJ040484). This result revealed misidentification and further morphological examination is needed.

Phylogenetic analysis of the partial $18 \mathrm{~S}$ and 28S D2/D3 were performed to examine the relationships of two study $P$. porosus isolates among other Paratrichodorus species sequenced using the same loci. The dendrogram inferred from SSU (Fig. 2) using Tylolaimophorus minor (Thorne, 1939) Goodey, 1963 and Diphtherophora obesus Thorne, 1939 as outgroups suggested that: $i$ ) all the selected tricho- dorids are in a monophyletic clade in relation to Tylolaimophorus minor with $100 \%$ posterior probability (pp); ii) both study isolates of $P$. porosus is in a well-supported ( $\mathrm{pp}=100 \%$ ) monophyletic clade with five Zhejiang isolates (GU645955, GU645868, GU645957, GU645865, GU645 949), 11 Yunnan isolates (GU645954, GU645862, GU645 952, GU645861, GU645860, GU645859, GU645950, GU645863, GU645864, GU645951, GU645953), three Fujian isolates (GU645867, GU645866, GU645956), one American isolate (JN123368) and one Portugal isolate (DQ345524) of P. porosus, one Greece (AM269896) and one American (AM087125) of P. teres isolate. One Brazil isolate (AJ438059) and one Portugal isolate (AJ438060) of 
$P$. porosus are in a separate clade close to $N$. renifer and $N$. monor which revealed they are not $P$. porosus. iii) Brazil isolate (AJ438059) and Portugal isolate (AJ438060) of $P$. porosus are in a monophyletic clade in relation to one Greece isolate (AM269897) and seven isolates of N. minor including four Yunnan isolates (GQ995706, GQ995707, GQ995705, GQ995708) and three Hainan isolates (GQ995710, GQ995703, GQ995704) with $100 \%$ posterior probability. This result supports they are not $P$. porosus.

The alignment for the D2/D3 of 28S rDNA included 43 sequences. Twenty-five Paratrichodorus, eight Nanidorus, eight Trichodorus nominal and two putative isolates were included in this analysis. Both studied $P$. porosus isolates all share identities of $99 \%$ with all 14 Chinese isolates of $P$. porosus, but $98 \%$ with two American ones (JN123405 and JN123406). Intraspecific sequence variations for $P$. porosus was $0-1.8 \%(0-13 \mathrm{nt})$. The identities of both $P$. porosus isolates with $P$. pachydermus are $82 \%-88 \%$, and $79 \%-83 \%$ with Trichodorus spp. (T. cylindricus, $T$. nanjingensis, T. pakistanensis, T. primitivus and T. similis), $79 \%$ with $N$. minor, $78 \%$ with $N$. renifer.

The tree inferred from D2/D3 of LSU (Fig. 3) using Tripyla filicaudata de Man, 1880 and Tripylina tamaki Zhao, 2009 as outgroups suggested that: $i$ ) all the selected trichodorids are in a monophyletic clade in relation to Tripyla filicaudata with $100 \%$ posterior probability; ii) two studied isolates of $P$. porosus are in a well-supported ( $\mathrm{pp}=100 \%$ ) monophyletic clade with all other Chinese isolates including six Zhejiang isolates (GU645843, GU645930, GU645933, EU827614, GU645840, GU645929), four Yunnan isolates (GU723295, GU645838, GU645931, GU645839), three Fujian isolates (GU645842, GU645934, GU645841), one Guangdong isolate (GU645932), and two American isolates (JN123406, JN123405) of $P$. porosus; iii) all $P$. porosus isolates, including study isolates SZ1 and SZ2, are closer to five Czech isolates (JN123399, JN123404, JN123402,

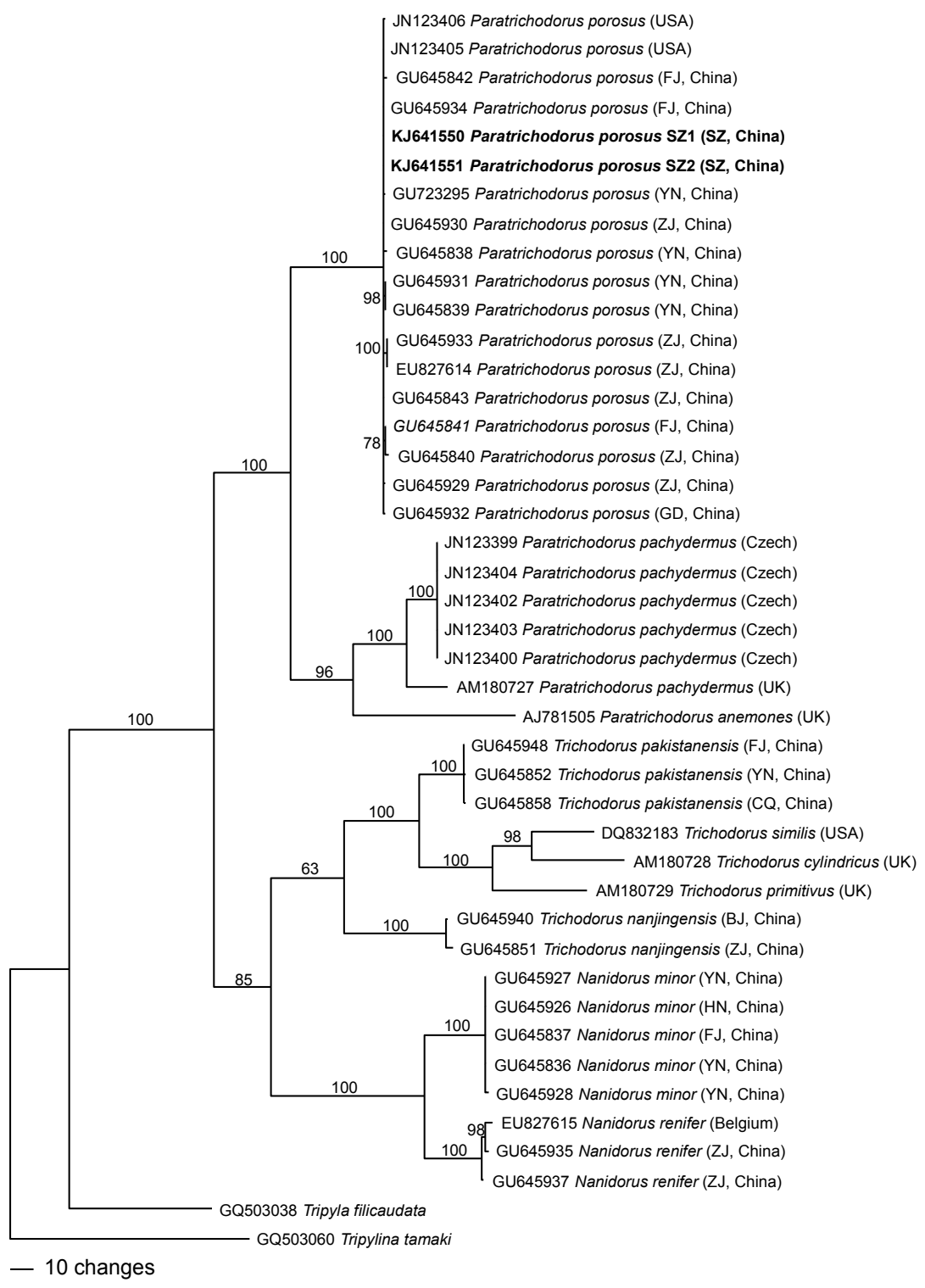

Fig. 3. The 10001 st Bayesian tree inferred from Paratrichodorus porosus $28 \mathrm{~S}$ D2/D3 under GTR $+\mathrm{I}+\mathrm{G}$ model $(-\operatorname{lnL}=5086.9248 ;$ freqA $=0.2229$; freqC $=0.2226$; freqG $=0.2994$; freqT $=0.2551 ; \mathrm{R}(\mathrm{a})=0.9556 ; \mathrm{R}(\mathrm{b})=2.4679 ; \mathrm{R}(\mathrm{c})=1.7546 ; \mathrm{R}(\mathrm{d})=0.1858 ; \mathrm{R}(\mathrm{e})=5.0248 ; \mathrm{R}(\mathrm{f})=1 ;$ Pinva $=0.2515$; 
JN123403, JN123400), one UK isolate (AM180727) of $P$. pachydermus and one UK isolate (AJ781505) of $P$. anemones than five Chinese isolates (GU645927, GU645926, GU645837, GU645836, GU645928) of N. minor and two Chinese isolates (GU645935, GU645937) and one Belgium isolate (EU827615) of $N$. renifer.

\section{Discussion}

A combined approach that uses morphological and molecular characters is often needed for discrimination of $\mathrm{Pa}$ ratrichodorus species at high confidence level. In this study, no apparent differences were found in morphological and morphometric characters between two isolates of $P$. porosus (SZ1 and SZ2) from different localities and vegetation. The analysis of DNA sequences of $18 \mathrm{~S}$ and 28S D2/D3 confirmed that these two isolates are identical, thus they were considered as the same species. Furthermore, morphological and morphometric characters of both isolates lie within the range of previous reported by Decraemer (1995), although the difference in the number of ventromedian advulvar body pores was observed among several Chinese isolates of $P$. porosus, i.e., one pair for both study isolates, $P$. porosus $\mathrm{SZ1}$ from $A$. mangium and $P$. porosus SZ2 from $G$. linearis in Shenzhen, two pairs for P. porosus from Camellia japonica and Prunus serrula in Zhejiang and Pyrus spp. in Yunnan, and three pairs from Magnoliaceae glance in Guangdong. Also, analysis of sequences of $18 \mathrm{~S}$ and $28 \mathrm{~S}$ D2/D3 indicated that the identities of two studied isolates with other isolates of $P$. porosus except for one Brazil isolate (AJ438059) and one Portugal isolate (AJ438060) are $99 \%-100 \%$, and molecular phylogenetic analysis revealed that these two isolates are in a monophyletic clade with all other isolates of $P$. porosus except for two isolates (AJ438059 and AJ438060) with $100 \%$ posterior probability. Thus, based upon morphological and molecular characterization, these two isolates from $A$. mangium and $G$. linearis, respectively, are the same species and were identified as $P$. porosus (Allen, 1957) Siddiqi, 1974. To our knowledge, this is the first report of this species on $A$. mangium and $G$. linearis.

\section{Acknowledgements}

The authors would like to thank Mr. Zhicong Li and Mr. Haohui Li for assistance with soil sample collection. This study was supported by a grant from Shenzhen Residential and Environmental Committee, China (SZGX2012118F-SCZJ). The first author received a co-scholarship of China Scholarship Council and Guangdong Department of Education.

\section{References}

AlleN, M. W. (1957): A review of the nematode genus Trichodorus with descriptions of ten new species. Nematologica, 2: $32-62$

Ayala, A., Allen, M. W. (1968): Transmission of the
Californian tobacco virus by three species of the nematode genus Trichodorus. J. Agric. Univ. Puerto Rico, 52: $101-125$ BARRIGA, R. (1965): Parasitism of camellias by some nematode species. Nematologica, 11: 34

Boutsika, K., Phillips, M. S., MacFarlane, S. A., Brown, D. J. F., Holeva, R. C., BloK, V. C. (2004): Molecular diagnostics of some trichodorid nematodes and associated tobacco rattle virus. Plant Pathol., 53: 110 116. DOI: 10.1046/j.1365-3059.2003.00938.x

Brown, D. J. F., BoAG, B. (1988): An examination of methods used to extract virus-vector nematodes (Nematoda: Longidoridae and Trichodoridae) from soil samples. Nematol. mediterr., 16: 93 - 99

ChÉvres-Román R, Gross, H. D., SAsser, J. N. (1971): The influence of selected nematode species and number of consecutive plantings of corn and sorghum on forage production, chemical composition of plant and soil, and water use efficiency. Nematropica, 1: $40-41$

CABI (2009): Paratrichodorus porosus. [Distribution map]. Distribution Maps of Plant Diseases (October) $\left(1^{\text {st }}\right.$ Edition), Map 1066

Christie J. R., Perry, V. G. (1951): A root disease of plants caused by a nematode of the genus Trichodorus. Science, 113: 491 - 493. DOI: 10.1126/science.113.2939.491-a DeCrAEMER, W. (1991): Stubby Root and Virus Vector Nematodes, Trichodorus, Paratrichodorus, Allotrichodorus and Monotrichodorus. In: NiCKLE, W. R. (Ed) Manual Of Agricultural Nematology. New York: Marcel Dekker Publisher, pp. $587-625$

DECRAEMER, W. (1995): The Family Trichodoridae: Stubby Root And Virus Vector Nematodes. Kluwer Academic Publishers, Boston, MA, 360 pp.

DeCraemer, W., BAUJARD, P. (1998): A polytomous key for the identification of species of the family Trichodoridae Thorne, 1935 (Nematoda: Triplonchida). Fundam. Appl. Nematol. 21: $37-62$

Duarte, I. M., Almeida, M. T. M., Duarte, M. M., Brown, D. J. F., NEILSON, R. (2011): Molecular diagnosis of trichodorid species from Portugal. Plant Pathol., 60: 586 - 594. DOI: 10.1111/j.1365-3059.2010.02401.x

Floyd, R., Abebe, E., PAPert, A., BlaXter, M. (2002): Molecular barcodes for soil nematode identification. Mol. Ecol., 11: 839 - 850. DOI: 10.1046/j.1365-294X.2002.01 485. $\mathrm{x}$

Golden, A. M., BIRChFIELD, W. (1972): Heterodera graminophila $\mathrm{n}$. sp. (Nematoda: Heteroderidae) from grass with key to closely related species. J. Nematol., 4: $147-154$ GoldEN, A. M. (1990): Preparation and mounting nematodes for microscopic observation. In: ZUCKERMAN, B. M., Mai, W. F., Krusberg, L. R. (Eds) Plant Nematology Laboratory Manual. Revised Edition, Amherst, MA, USA: University of Massachusetts Agricultural Experimental Station, pp. $200-201$

HoOPER, D. J. (1970): Handling, fixing, staining and mounting nematodes. In: SouTHEY, J. F. (Ed) Laboratory Methods For Work With Plant And Soil Nematodes. $5^{\text {th }}$ Edition, London: Her Majesty's Stationery Office, pp. 39 - 54 
Huelsenbeck, J. P., Ronquist, F. (2001): Mr Bayes: Bayesian inference of phylogenetic trees. Bioinformatics, 17: $754-755$

HunT, D. J. (1993): Aphelenchida, Longidoridae And Trichodoridae: Their Systematics And Bionomics. Wallingford, UK, CABI Publishing, 368pp.

KANZAKI, N., FUTAI, K. (2002): A PCR primer set for determination of phylogenetic relationships of Bursaphelenchus species within the xylophilus-group. Nematology, 4: 35 - 41. DOI: 10.1163/156854102760082186

Kumari, S., Subbotin, S. A. (2012): Molecular characterization and diagnostics of stubby root and virus vector nematodes of the family Trichodoridae (Nematoda: Triplonchida) using ribosomal RNA genes. Plant Pathol., 61: 1021 - 1031. DOI: 10.1111/j.1365-3059.2012.02598.x

LARGET, B., SimON, D. L. (1999): Markov Chain Monte Carlo algorithms for the Bayesian analysis of phylogenetic trees. Mol. Biol. Evol., 16: 750 - 759

LiaO, L., Chi, Y., ShaO, X., Zhang, W., XU, M., ZhuO K., CHEN Q. (2011): A description of virus vector nematode Paratrichodorus porosus in Guangdong. J. Inspect. Quarant., 21: 42 - 44

Mullin, P. G., Harris, T. S., Powers, T. O. (2005): Phylogenetic relationships of Nygolaimina and Dorylaimina (Nematoda: Dorylaimida) inferred from small subunit ribosomal DNA sequences. Nematology, 7: 59 79. DOI: $10.1163 / 1568541054192199$

NishizAWA, T. (1973): Pathogenecity of Trichodorus porosus to Chinese yam. Jap. J. Nematol., 3: 33 - 37

NunN, G. B. (1992): Nematode Molecular Evolution. PhD dissertation, UK: University of Nottingham

PLANTWISE: KnowledgeBank: Plantwise Technical Factsheet. Retrieved from http://www.plantwise.org/ KnowledgeBank/Datasheet.aspx?dsID $=44684$

PosAdA, D., CRANDAll, K. A. (1998): Modeltest: testing the model of DNA substitution. Bioinformatics, 14: $817-$ 818. DOI: 10.1093/bioinformatics/14.9.817

Riga, E., Karanastasi, E., Oliveira, C. M. G., NeILson, R. (2007): Molecular identification of two stubby root nematode species. Amer. J. Potato Res., 84: $161-167$

RECEIVED JULY 8, 2014
SAN Diego Supercomputer Center: Biology Workbench. Bioinformatics and Computational Biology Group, Department of Bioengineering, UC San Diego, San Diego, CA, USA Retrieved from http://workbench.sdsc.edu SEED Association of THAILAND: Notification of Ministry of Agriculture and Cooperatives. Re: Specification of plant pests as prohibited articles under the Plant Quarantine Act B.E. 2507 (No. 6) B.E. 2550. Retrieved from http://www.seed.or.th/english/documents_eng/MOAC_Not ification_Quarantine_pest_English_version.pdf

Sheedy, J. G., Clewett, T. G., Hodda, M., ThOMPson, J. P. (2010): First record of stubby-root nematode (Paratrichodorus porosus) associated with barley in Australia. Aust. Plant Dis. Notes, 5: 66 - 69

SIDDIQI, M. R. (1974): Systematics of the genus Trichodorus Cobb, 1913 (Nematoda: Dorylaimida), with descriptions of three new species. Nematologica, 19: 259 - 278

TAYLOR, C. E., BROWN, D. J. F. (1997): Nematode Vectors of Plant Viruses. CAB International, $296 \mathrm{pp}$.

Williams, B. D., SchranK, B., HuYNH, C., SHOWNKEEN, R., WAterston, R. H. (1992): A genetic mapping system in Caenorhabditis elegans based on polymorphic sequence-tagged sites. Genetics, 131: $609-624$

YE, W. (1996): Applying Microsoft Works spreadsheet in statistics for morphometric data of nematode identification. Afro-Asian J. Nematol., 6: 203 - 211

Ye, W., GiBlin-Davis, R. M., BraAsCH, H., MORRIS, K., ThOMAS, W. K. (2007): Phylogenetic relationships among Bursaphelenchus species (Nematoda: Parasitaphelenchidae) inferred from nuclear ribosomal and mitochondrial DNA sequence data. Mol. Phylogenet. Evol., 43: 1185 1197. DOI: 10.1016/j.ympev.2007.02.006

ZhaO, L., XIE, H., Wu, M., Zhong, G., FenG, Z. (2005): Description of Trichodoridae nematodes from rhizosphere of pear trees in Kunming region. J. South China Agri. Univ., 26: $59-61$

Zheng, J., JiAng, L., Liang, D., Brown, J. F. (2004): Three trichodorid species (Nematoda: Trichodoridae) occurring in China. Helminthologia, 41: $39-44$ 